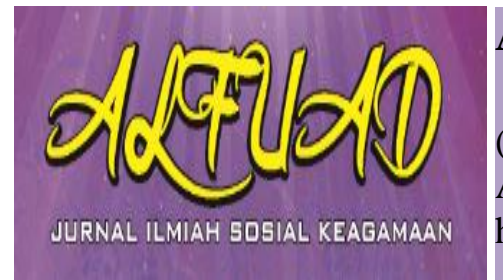

ALFUAD JOURNAL, 3 (2), 2019, (76-84)

(Print ISSN 2614-4786)

Available Online at

http://ecampus.iainbatusangkar.ac.id/ojs/index.php/alfuad

\title{
PENGUATAN NILAI KEAGAMAAN BAGI KELOMPOK PENGAJIAN REMAJA DI KELURAHAN TANAH SIRAH PIAI NAN XX
}

\section{Iswadi}

Institut Agama Islam Negeri Batusangkar Email: iswadi@iainbatusangkar.ac.id

\begin{abstract}
The potential of religion that has existed when humans are born if not treated properly, then that potential will experience fade or disappear altogether, so people in their lives assume that religion is not important in their lives. This study discusses the strengthening of the model of religious guidance for adolescents through wirid activities in Tanah Sirah Piai Nan XX Lubuk Begalung. This study uses a qualitative descriptive approach where researchers describe the overall model of adolescent coaching on intellectual, spiritual and social aspects as well as ideas related to strengthening the coaching model by forming an organization, increasing activities by carrying out dawn in congregation, Maghrib reciting and giving rewards.
\end{abstract}

Keywords: Fostering, Islamic, Religion,Teenager

\section{PENDAHULUAN}

Pada umumnya pengalaman agama seseorang ditentukan oleh pendidikan, pengalaman dan latihan yang dilalui pada masa kecil dulu. Seseorang yang pada waktu kecil tidak pernah mendapatkan didikan agama, maka pada masa dewasa dia tidak akan merasakan pentingnya agama dalam kehidupannya. (Daradjat, 1993: 48).

Dalam perkembangan, remaja lebih tertarik kepada agama dan keyakinan spiritual dibanding anak-anak. Pemikiran abstrak remajalah mendorong untuk melakukan pencarian identitas yang remaja lakukan dan pada akhirnya terbawa kepada masalah-masalah agama dan spiritual. (Santrock, 2003: 460).

Pada masa remaja, perkembangan intelektual telah mengalami perkembangan. Ditandai dengan mampu mengembangkan fikiran formal, mampu menggunakan fikiran abstraknya. Melibatkan remaja dalam suatu kegiatan akan lebih memberikan manfaat yang positif bagi perkembangan kognitifnya. Misalnya, menulis puisi, lomba karya ilmiah, lomba menulis cerpen dan lain sebagainya (Santrock, 2003: 29).

Salah satu bentuk kegiatan yang dapat memberikan pendidikan baik dari segi intelektual, rohani dan sosial adalah kegiatan wirid remaja. Ini sejalan dengan 
apa yang dikatakan oleh Agus Effendi dalam Alfitri (2001: 57) setidaknya ada tiga kompleks pemberdayaan yang mendesak untuk diperjuangkan dalam konteks keumatan masa kini, yakni pembinaan dalam tataran ruhaniah, intelektual dan ekonomi.

Berdasarkan pengamatan di Tanah Sirah Piai Nan XX dari segi aktifitas keagamaan, remaja jarang pergi ke mushalla atau ke masjid untuk melaksanakan shalat berjamaah, bahkan kalau ada peringatan hari besar Islam remaja jarang mengikuti kegiatan tersebut. Dilihat dari segi sosial remaja tidak begitu peduli terhadap lingkungan di sekeliling remaja. Ini terlihat ketika ada gotong royong remaja tidak ada yang ikut berpartisipasi, pada acara takziyah remaja juga jarang hadir. Dilihat dari segi intelektual keagamaan, remaja tidak begitu antusias dalam mendengarkan materi yang disampaikan pada kegiatan wirid remaja.

Dalam kehidupan sehari-hari berbagai dampak dari kemajuan teknologi menjadikan remaja tidak peka terhadap lingkungan. Sibuk dengan diri sendiri, seperti memainkan gadged, WA, Facebook, Instagram Games dan lain sebagainya. Inilah kondisi riil yang ditemukan pada kehidupan remaja saat sekarang.

Penelitian yang telah dilakukan oleh peneliti Ahmad Karmizi membahas tentang bentuk-bentuk kegiatan dan kendala yang dihadapi pada kegiatan remaja seperti wirid remaja, perilakuperilaku menyimpang remaja. Dalam penelitian tersebut ditemukan kendalakendala dan penyebab perilaku menyimpang dari remaja. Sedangkan dalam penelitian ini, penulis membahas tentang peningkatan sumber daya manusia khususnya para remaja pada tiga aspek, yaitu aspek rohani, aspek intelektual dan aspek sosial.

Istilah remaja berasal dari bahasa Latin yaitu adolescence yang artinya tumbuh untuk mencapai kematangan. Istilah ini mengalami perkembangan arti yang lebih luas, mencakup kematangan mental, emosional, sosial dan fisik. (Ali, 2004: 9).

Zakiah Darajat berpendapat, masa remaja sebagai masa peralihan yang ditempuh oleh seseorang dari kanakkanak menuju dewasa. belum matang dalam aspek biologis, psikologis dan sosial. dan belum bisa diberi tanggung jawab atas segala hal (Darajat, 1991: 6970). 
Sesuai dengan fase perkembangan, remaja mempunyai banyak angan-angan atau keinginan yang hendak diwujudkan di masa depan, namun sesungguhnya remaja belum memiliki banyak kemampuan yang memadai untuk mewujudkan semua itu (Ali, 2004 : 16). Tarik menarik antara angan-angan dan kemampuan yang masih belum memadai mengakibatkan remaja diliputi oleh perasaan gelisah. Inilah gambaran yang dialami oleh anak-anak yang menginjak masa remaja. Keadaan tersebut dapat dikendalikan dengan cara menyalurkan pada hal-hal yang positif. Sebaliknya keadaan ini akan dapat menjerumuskan anak remaja pada kesesatan dan kerusakan bila tidak diarahkan dan dibimbing kejalan yang baik.

Dalam perkembangannya remaja lebih merasa tertarik kepada agama dan keyakinan spiritual daripada anak-anak. Pemikiran abstrak remaja yang semakin meningkat dan pencarian identitas yang remaja lakukan membawa remaja kepada masalah-masalah agama dan spiritual (Santrock, 2003:460). Keyakinan agama mempengaruhi perilaku manusia, bukan hanya secara individual, tetapi juga sosial (Mubarok , 1999: 16).
Penghayatan para remaja terhadap pengamalan ajaran agama dan perilaku beragama berkaitan dengan faktor perkembangan remaja itu sendiri (Jalaluddin, 2003: 74). Lingkungan keagamaan, baik dari lembaga-lembaga pendidikan keagamaan, tempat-tempat peribadatan, maupun kegiatan-kegiatan keagamaan adalah sangat penting dalam pembentukan jiwa remaja.

Menurut Arifin pembinaan yaitu usaha manusia secara sadar untuk membimbing dan mengarahkan kepribadian serta kemampuan, baik dalam pendidikan formal maupun non formal (Arifin, 2008: 30). Pembinaan memberikan arah penting dalam masa perkembangan remaja, khususnya dalam perkembangan sikap dan perilaku. Untuk itu, pembinaan bagi remaja pasti sangat diperlukan sejak dini guna memberikan arah dan penentuan pandangan hidupnya Dalam pandangan Islam, pembinaan harus merupakan gerakan tanpa henti. Hal ini sejalan dengan paradigma Islam sendiri sebagai agama gerakan atau perubahan (Nanih, 2001: 41).

\section{METODE}

Penelitian ini menggunakan metode deskriptif kualitatif, yaitu menggambarkan keadaan subyek atau obyek penelitian (seseorang, lembaga, 
masyarakat, dan sebagainya) pada saat sekarang berdasarkan fakta-fakta yang tampak atau sebagaimana adanya. Pada penelitian ini, peneliti menggambarkan secara menyeluruh model pembinaan remaja di Kelurahan Tanah Sirah Piai Nan XX serta gagasan terkait penguatan atas model pembinaan remaja.

Teknik pengumpulan data dengan wawancara, observasi dan studi dokumentasi, setelah data terkumpulkan maka dianalisa dengan berbagai proses yaitu, menyeleksi data, mereduksi, mengklasifikasi, memberi kode terhadap data-data dan terakhir mendeskripsikan data untuk mendapatkan maksud dan makna sesuai dengan tujuan penelitian.

Setelah data dikelompokkan, kemudian dihubungkan dengan teori sesuai dengan permasalahan penelitian. Untuk menguji dari keabsahan data dilakukan triangulasi yaitu dengan melakukan pengecekan terhadap sumber data dan teori yang terkait dengan penelitian. Proses ini dilakukan terus menerus sampai diyakini tidak ada lagi perbedaan dan yang perlu dikonfirmasikan kepada responden (Bungin, 2006: 192). Kemudian setelah data diuji keabsahan dengan melakukan pengecekan terhadap sumber data dan teori dan tidak ada lagi kekeliruan dalam menganalisa hasil penelitian, barulah diambil kesimpulan dari penelitian ini.

\section{HASIL DAN PEMBAHASAN}

Remaja Masjid adalah organisasi yang mewadahi aktivitas remaja muslim dalam memakmurkan Masjid. Remaja Masjid merupakan salah satu alternatif wadah pembinaan remaja yang baik dan dibutuhkan umat.

Organisasi remaja masjid juga telah menjadi suatu fenomena bagi kegairahan para remaja muslim dalam mengkaji dan menda'wahkan Islam di Indonesia. Masyarakat juga sudah semakin lebih bisa menerima kehadiran remaja dalam memakmurkan Masjid. Disadari bahwa untuk memakmurkan Masjid diperlukan organisasi yang mampu beraktivitas dengan baik. Organisasi Remaja Masjid memerlukan para aktivis yang mumpuni dan profesional.

Remaja masjid yaitu suatu organisasi atau wadah perkumpulan remaja muslim yang menggunakan masjid sebagai pusat aktivitas (Siswanto, 2010:48). Ini berarti kegiatan yang berorientasi pada Masjid selalu menjadi program yang paling utama. Masjid sebagai sentral pengembangan dan pemberdayaan mengambil satu peran penting yaitu mengembangkan sayap 
dakwah dengan target para remaja yang akan melanjutkan tongkat estapet dari generasi sebelumnya.

Berdasarkan wawancara dengan pembina wirid remaja di Masjid dan Mushalla di Kelurahan Tanah Sirah Piai Nan XX dan informasi yang diberikan oleh para informan. Dari 12 ( dua belas) rumah ibadah di Kelurahan Tanah Sirah Piai Nan XX, hanya 4 ( empat) rumah ibadah yang memiliki kepengurusan, diantaranya adalah Masjid Al-Hasanah, Mushalla Al-Hidayah, Mushalla Muhajirin dan Mushalla Ubudiyah.

Berdasarkan situasi tersebut kegiatan wirid remaja terkadang mengalami kevakuman di dalam melaksanakan aktifitasnya. Struktur kepengurusan dalam suatu organisasi mempunyai peran yang sangat besar untuk menata dan mengkondisikan kegiatan agar sesuai dengan harapan semua pihak, baik itu pengurus wirid remaja, para remaja, pengurus masjid dan mushalla maupun masyarakatpada umumnya.

Pembina kegiatan wirid remaja di Kelurahan Tanah Sirah Piai Nan XX adalah ustadz yang tinggal di masjid dan mushalla tersebut. Kegiatan wirid remaja sangat memerlukan perhatian dari pengurus Masjid dan Mushalla, namun kenyataannnya perhatian tidak diberikan sepenuhnya pada kegiatan tersebut.

Berdasarkan pernyataan dari pembina wirid remaja di Mushalla Darul Taqwa, Masjid Baitul Ihsan dan Mushalla Aisyiyah, kegiatan wirid remaja hanya diserahkan kepada kami yang tinggal di masjid atau mushalla dan pengurus tidak terlalu peduli terhadap kegiatan ini, tentunya dalam pelaksanaan kegiatan ini tidak maksimal dilakukan karena kurangnya dukungan dari pengurus. Untuk suksesnya kegiatan wirid remaja, tentunya membutuhkan dukungan dari pengurus masjid dan mushalla, karena tanpa dukungan pengurus kegiatan wirid remaja tidak akan berjalan dengan baik dan terkesan asal-asalan atau hanya sekedar melepas tanggung jawab saja.

\section{Pembinaan Intelektual Terhadap Remaja}

Kegiatan wirid remaja pada Masjid dan Mushalla di Kelurahan Tanah Sirah Piai Nan XX terkadang dilaksanakan 1 (satu) kali dalam satu bulan, ada juga yang melaksanakan 2 (dua) kali dalam satu bulan bahkan sampai 3 (tiga) kali dalam satu bulan. Materi yang disampaikan kepada remaja dalam pengajian atau ta'lim mencakup: akidah, fiqih, akhlak, tarikh, tafsir dan tahsin Al-Qur'an serta masalah-masalah 
aktual yang sedang berkembang di masyarakat. Secara teoritis pendidikan sebagai komponen utama pembangunan SDM harus berfungsi sebagai wacana untuk mewariskan norma-norma dan nilai-nilai masyarakat, melalui pendidikan, individu akan memperoleh pengetahuan dan keterampilan dalam kehidupan bermasyarakat yang semakin kompleks.

Penerapan metode yang disampaikan pembina dan ustadz pemateri tidak banyak menggunakan metode demonstrasi dan praktek. Padahal metode ini sangat menunjang kesuksesan dari materi yang disampaikan kepada remaja. dalam konsep pembangunan sumber daya manusia memakai konsep functionalist, dimana pada konsep ini pembina wirid remaja lebih kepada mentransfer ilmu dan nilai-nilai kepada remaja. Tetapi alangkah lebih baiknya jika dilengkapi dengan dorongan kepada individu untuk mengembangkan potensi yang ada pada dirinya, inilah yang disebut dengan perspektif liberal dalam konsep pembangunan sumber daya manusia.

Secara garis besar pembinaan dari segi intelektual kepada remaja telah dilakukan oleh pembina dan pemateri dalam kegiatan wirid remaja, tinggal penerapannya dalam kehidupan seharihari.

\section{Pembinaan Rohani terhadap Remaja}

Pembinaan rohani yang dilakukan kepada remaja umumnya hanya sebatas pemberian pengajian, bahwa shalat, puasa, zakat, sedekah adalah wajib. Namun dalam bentuk penerapannya dilapangan hanya beberapa remaja yang melakukan shalat berjamaah di masjid atau mushallah. Itu semua membutuhkan dorongan dari orang tua agar para remaja memakmurkan Masjid. Walaupun demikian pembinaan dari segi rohani sudah dilakukan pada kegiatan wirid remaja pada masjid dan mushalla di Kelurahan Tanah Sirah Piai Nan XX.

Berdasarkan realitas di atas, secara teoritis, argumennya adalah bila suatu kegiatan hanya dilakukan dalam bentuk teori saja tanpa adanya suatu penerapan dari teori tersebut, maka akan terjadi ketidakseimbangan yang menyebabkan tidak berjalannya suatu kegiatan. Dan apabila suatu kegiatan dipandang mempunyai manfaat tetapi tidak didukung oleh semua unsur, maka manfaat dari kegiatan tersebut pun tidak akan diperoleh.

Pembentukan nilai-nilai pada masa remaja, dilakukan dengan cara identifikasi dan imitasi terhadap tokoh 
yang menjadi panutan remaja atau melakukan imitasi terhadap perilaku orang lain. Keterlibatan remaja dalam organisasi keagamaan atau ibadah yang dilakukan oleh suatu agama mampu menjadikan remaja bersikap sesuai dengan norma yang dianut, baik itu norma agama maupun norma masyarakat. Untuk itu diperlukan bimbingan pemahaman yang baik terhadap remaja, agar di usia ini remaja mampu memantapkan keyakinan terhadap suatu agama yang menjadi jalan hidup remaja.

Dalam upaya untuk meningkatkan pembinaan rohani kepada remaja, pembina wirid remaja bisa menerapkan sedikit paksaan sosial kepada remaja, dengan tujuan pada awalnya merasa terpaksa untuk shalat berjamaah di masjid dan mushalla yang dikaitkan dengan nilai wirid remaja, namun lama-kelamaan remaja tersebut akan merasa terbiasa untuk shalat berjamaah tanpa ada pemaksaan pada dirinya. Metode ini sangat bagus digunakan untuk melakukan pembiasaan terhadap remaja, kalau tidak demikian remaja akan menganggap kegiatan wirid remaja hanya seremonial saja.

\section{Pembinaan Sosial Terhadap Remaja}

Pelaksanaan kegiatan wirid remaja pada masjid dan mushalla di
Kelurahan Tanah Sirah Piai Nan XX, pada umumnya tidak melakukan evaluasi terhadap kegiatan, sehingga terkesan kegiatannya hanya itu-itu saja dan pada akhirnya bisa menyebabkan remaja malas mengikutinya.

Secara teoritis argumentasinya adalah bahwa dalam membangun suatu masyarakat ada tiga tahapan yang dilakukan oleh Rasulullah, yaitunya takwin, tanzim dan taudi', jika ketiga tahapan tersebut terlaksana dengan baik, maka akan tercipta suatu masyarakat yang berkualitas. Namun kenyataanya Pelaksanaan wirid remaja pada masjid dan mushalla di Kelurahan Tanah Sirah Piai Nan XX dalam mengembangkan aspek sosial remaja hanya sampai kepada tahapan takwin yaitu pelaksanaan dakwah bil lisan sebagai ikhtiar sosialisasi dari semua bentuk ajaran Islam. Sedangkan tahapan tanzim dan taudi' belum terlaksana dengan baik.

Salah satu permasalahan yang dialami oleh remaja dalam proses sosialisasinya adalah bahwa tidak jarang masyarakat bersikap tidak konsisten terhadap remaja. Disatu sisi remaja dianggap sudah beranjak dewasa, disisi lain remaja tidak diberikan kesempatan dan peran sebagaimana orang dewasa. 
Keadaan seperti ini seringkali menjadi penghambat perkembangan sosial remaja.

Lingkungan masyarakat yang kondusif sangat diharapkan bagi perkembangan hubungan sosial remaja. Remaja tengah mencari jati diri, sehingga faktor keteladanan dan kekonsistenan nilai dan norma dalam masyarakat menjadi hal yang penting bagi remaja. Masa remaja sebagai masa yang sangat potensial dan dapat berkembang ke arah yang positif maupun negatif, maka intervensi pendidikan dan bimbingan sangat diperlukan untuk mengarahkan perkembangan potensi remaja, agar berkembang ke arah positif dan produktif.

Dalam menyiapkan mutu SDM produktif, terdapat parameter yang digunakan dengan rumusan konseptual sebagai berikut: (1) peningkatan kualitas iman dan takwa, (2) peningkatan kualitas hidup, (3) peningkatan kualitas kerja, (4) peningkatan kualitas karya dan (5) peningkatan kualitas fikir (Aziz, 2005:: 152). Dengan demikian diperlukan suatu pembinaan terhadap generasi muda khususnya kepada para remaja.

Pada tataran peningkatan rohani terhadap remaja perlu diadakan gerakan shalat subuh berjamaah, maghrib dan isya dan ditambah dengan maghrib mengaji, tentu hal tersebut harus didukung oleh pemerintah setempat dan dinas terkait dan bagi remaja yang istiqomah melakukan hal tersebut diberikan reward.

\section{KESIMPULAN}

Pembinaan Keagamaan Islam bagi remaja di Kelurahan Tanah Sirah Piai Nan XX dilaksanakan melalui kegiatan wirid remaja pada spek intelektual, rohani dan sosial. Pembinaan tersebut mendapat respon yang baik dari masyarakat dan dianggap sebagai cara yang efektif untuk menyiapkan generasi Islam, sehingga perlu dilakukan penguatan model pembinaan keagamaan Islam melalui pembentukan organisasi remaja yang pengurusnya adalah remaja itu sendiri dan juga perlu ditingkatkan kegiatan dengan melakukan gerakan subuh berjamaah, maghrib mengaji dan pemberian reward bagi remaja yang aktif.

\section{DAFTAR PUSTAKA}

Alfitri. (2001). Community Development (Teori dan Aplikasi). Yogyakarta: Pustaka Pelajar.

Ali, M., \& Asrori, A. (2004). Psikologi Remaja Perkembangan Peserta Didik, Cet. I. Jakarta: Bumi Aksara.

Almasri, \& Deswinar, D. (2014). Peran Program Pemberdayaan Masyarakat Desa dalam Pembangunan Pedesaan. Jurnal El-Riyasah, 5(1), 44-47.

Aslati. (2018). Pemberdayaan Remaja Berbasis Masjid (Studi Terhadap Remaja Masjid Di Labuh Baru 
Barat). Jurnal Masyarakat Madani, 3, 2.

Aziz, M. A. (2009). Ilmu Dakwah. Jakarta: Kencana.

,dkk. (2009). Dakwah

Pemberdayaan Masyarakat

Paradigma Aksi Metodologi, Cet.

Ke-1. Yogyakarta: Pustaka Pesantren.

Daradjat, Z. (1993). Ilmu Jiwa Agama. Jakarta: Bulan Bintang

Rosanti, E., \& Andarini, D. Y. (2017). Program Pendampingan

Pembentukan Pos Daya Kesehatan Kerja pada Petani di Desa Demangan Ponorogo. Jurnal Pemberdayaan Masyarakat, 2(2), 92.

Harlock, E. B. (2003). Psikologi Perkembangan Suatu Pendekatan Penting Kehidupan, Edisi $V$. Jakarta: Erlangga.

Ife, J. \& Tesoriero, F. (2008). Community Development: Alternatif Pengembangan Masyarakat Di Era Globalisasi. Yogyakarta: Pustaka Pelajar.

Arifin, M. (2008). Hubungan Timbal Balik Pendidikan Agama, Jakarta: Bulan Bintang.
Machendrawaty, N. \& Ahmad, S. A. (2001). Pengembangan Masyarakat Islam Dari Ideology, Strategi Sampai Tradisi. Bandung: PT Remaja Rosdakarya. Noor, M., (2011) Pemberdayaan Masyarakat. Jurnal Ilmiah CIVIS, 1(2), 91.

Rukminto, I. (2008). Intervensi Komunitas Pengembangan Masyarakat Sebagai Upaya Pemberdayaan Masyarakat. Jakarta: Rajawali Pers.

Santrock, J. W. (2003). Adolescence (Perkembangan Remaja). Jakarta: Erlangga.

Sururi, A. (2015). Pemberdayaan Masyarakat Melalui Program Pembangunan Infrastruktur Perdesaan dalam Meningkatkan Kesejahteraan Masyarakat Kecamatan Wanasalam Kabupaten Lebak. Jurnal Administrasi Negara, 3(2), 5.

Saugi, W., \& Sumarno. (2015). Pemberdayaan Perempuan Melalui Pelatihan Pengolahan Bahan Pangan Lokal. Jurnal Pendidikan dan Pemberdayaan Masyarakat, 2(2), 229. 